\title{
Revisiting the FDI-Growth Nexus: ARDL Bound Test for BRICS Standalone Economies
}

\author{
Mohammad I. Elian ${ }^{1}$, Nabeel Sawalha ${ }^{2} \&$ Ahmed Bani-Mustafa ${ }^{3}$ \\ ${ }^{1}$ Department of Economics and Finance, Gulf University for Science and Technology (GUST), Kuwait \\ ${ }^{2}$ Department of Management, Gulf University for Science and Technology (GUST), Kuwait \\ ${ }^{3}$ Department of Mathematics and Physics, College of Engineering, Australian College of Kuwait (ACK), Kuwait \\ Correspondence: Ahmed Bani-Mustafa, Department of Mathematics and Physics, College of Engineering, \\ Australian College of Kuwait (ACK), Kuwait
}

Received: April 13, 2020

Accepted: May 12, 2020

Online Published: May 13, 2020

doi:10.5539/mas.v14n6p1

URL: https://doi.org/10.5539/mas.v14n6p1

\begin{abstract}
In this paper the author tests for the short-run dynamics and long-run cointegration relationship between foreign direct investment (FDI) inflows and economic growth for the BRICS (Brazil, Russia, India, China, and South Africa) standalone economies controlling for real exchange rate, trade openness, and domestic investment. The autoregressive distributed lag (ARDL) bounds testing method of cointegration is used to test for the long-run relationship of our FDI time series model by investigating annual macroeconomic datasets for the years 1981 to 2018 (inclusive). Coupled with the ARDL, the error correction model is applied to test for the short-run dynamics, while the Toda Yamamoto test is used to examine the causality direction between the constructs of interest. The Breusch-Godfrey and Ljung-Box are used as diagnostic tests for the ARDL assumptions of normality, independency, and autocorrelation in residuals, while the Breusch-Pagan-Godfrey test is used to test for heteroscedasticity. According to the short-run estimates, all variables have a significant lagged impact on FDI inflows with slight differences among countries. As for the long run, estimates reveal a positive and significant impact of GDP on FDI inflows for Russia, India, China, and South Africa but a positive and insignificant relationship for Brazil. The long-run estimates for the controlling variables evidence varied results among the BRICS countries. In contrast to Brazil and Russia, the Toda Yamamoto causality test discloses a significant and unidirectional flow between the GDP growth and FDI inflows for India, China, and South Africa. The results have meaningful implications for policy reform structures, economic integration among economies, multinational firms, and portfolio managers.
\end{abstract}

Keywords: FDI inflows, economic growth, exchange rate, trade openness, ARDL, cointegration

\section{Introduction}

The intrarelationship between foreign direct investment (FDI) and economic growth has been extensively deliberated by academics, professionals, and government policy makers as FDI inflows have become a crucial input for economic development. FDI inflow alleviates the saving-investment imbalance and provides the host economy with positive economic externalities, domestic capital formation, technology spillover, human capital perfections, and capital structure variation (Abdouli \& Hammami, 2017; Asongu et al., 2018; Dinh et al., 2019; Makiela \& Ouattara, 2018). Furthermore, FDI not only confirms current economic growth by boosting production efficiency and employment rates but also underwrites prospective future growth by bringing superior technological know-how and management skills to the recipient country (Chakraborty et al., 2012).

Thus far, most host economies have responded to the proposition that investment capacity in the host country is totally imperfect unless it is appended by FDI inflow; therefore they undergo extensive market-oriented reforms and structural macroeconomic alterations to overcome distortions in their economies (Dinh et al., 2019; Kathuria, 2019). Such transformation reforms and similar measures have started by easing home currency exchange rate controls and allowing the market conditions to control for the exchange rate of the currency and its volatility. The supplementary reform adjustment is the relaxation of trade boundaries, given the economic structural changes caused by globalization that endorse economic integration and trade liberalization among developing and transition economies. Intrinsically, trade openness has become prevalent over the past three decades as a 
result of the much-remarked-upon restriction of import substitution-based development strategies and the guidance of the international credit institutions, such as the IMF and the World Bank, which have often made their support conditional on trade liberalization of an economy (Zahonogo, 2016). This motivates countries to adopt the export-oriented development strategy and offer more inducements to invite FDI.

On a standalone economy basis, in this paper we test for the short-run dynamics and long-run cointegrating relationship between FDI inflow and economic growth for the BRICS countries, namely Brazil, Russia, India, China, and South Africa, while controlling for real exchange rate, trade openness, and domestic investment as proposed influential variables (Note 1). Contrary to general agreement that FDI is an essential factor for economic growth, we argue that empirical results are inconsistent on whether any long-run cointegration relationship exists between the two macrovariables, and as such, what type of causal relationship may exist (Note 2).

We also argue that testing for the long-run cointegration relationship between FDI and growth would lay the foundation for formulating rigorous economic reforms to sustain economic growth in the host country. Additionally, testing for the causal relationship between FDI inflow and economic growth has become vital because BRICS countries are restructuring their overall policy modeling while competing to attract more FDI inflow in light of rising currency volatility against hard currencies. This may be quite true given the differences among the BRICS members in terms of their global trade-oriented policies and their export structure and trends. For instance, Chinese and Indian exports are dominated by manufactured goods, while Russian and Brazilian exports are dominated by raw material, oil, and gas. The BRICS countries also differ in terms of exports trend, imports structure, and economic efficiencies. For example, while Brazil and India pay less attention to exports of their products, Russia and China are well focused on exports.

Econometrically, we use the autoregressive distributed lag (ARDL) bounds testing method of cointegration to test for our FDI time series model by investigating annual macroeconomic datasets for the years 1981 to 2018 (inclusive). The stationary condition of the modeled variables is tested using Augmented Dickey-Fuller (Dickey \& Fuller, 1979) and Phillips-Perron (Phillips \& Perron, 1988). The ARDL assumptions of normality and independence of residuals are checked by using the diagnostic tests Breusch-Godfrey and Ljung-Box for autocorrelation in residuals, while the heteroskedasticity is checked by applying the Breusch-Pagan-Godfrey test. Ramsey's RESET test is used for any model misspecification in our model. Stability of the coefficients is proven through the cumulative sum (CUSUM) and the cumulative sum of square (CUSUMSQ) of recursive residuals. The Toda Yamamoto (Toda \& Yamamoto, 1995) test is used to test for the cause-and-effect direction among variables of interest.

This paper contributes to the literature in the following three respects. First, although the majority of FDI studies have a focus on panel investigations, a single-country complementary test is needed based on the heterogeneous relationship between FDI and growth and because the impact of growth on FDI inflow is said to be larger in open and advanced economies with an educated workforce and developed financial markets. Therefore, testing for the long-run relationship between FDI and economic growth in a single economy base would add value to the economic development literature and provide insights for policy makers to stimulate higher rates of FDI inflow to their economies. Second, our model provides emphasis on the role of the host economy's trade openness (imports and exports) and domestic investment (capital formation) toward attracting steady and sustainable FDI inflow as a prominent growth factor, particularly for these emerging economies. Finally, using the ARDL bound test (Pesaran et al., 2001) that models the stationary variables at different lags (I[0] and I[1]) and tests their cointegration would overcome the limitations of the traditional cointegration tests (Johansen, 1991) that require all variables to be of order I(1).

The rest of this paper is structured as follows: In section 2 we review the related literature, while in section 3 we present the methodology. In section 4 we outline the data description and empirical analysis. A discussion of the results is presented in section 5. Concluding remarks, together with their policy implications, are given in section 6.

\section{Literature Review}

As per the empirical results, the positive impact of economic growth on FDI inflow is extensively demonstrated by several studies that count economic growth as a precondition for attracting and absorbing FDI toward the host economy (Asongu et al., 2018; Gherghina et al., 2019; Maryam \& Mittal, 2020; Mittal \& Mittal, 2019). Nonetheless, other studies have confirmed the negative association between economic growth and FDI inflow (see Mencinger [2003] for Eastern European countries and Sağlam [2017] for European transition countries). The empirical inferences on the FDI and currency exchange rate relationship are far from unanimous. No 
association between the two macrovariables is evidenced, given perfect capital flexibility in which risk-adjusted expected returns on all assets will be equalized (Vita \& Abbott, 2007). The positive association between the two variables was also concluded by Campa (1993), who reported that appreciation in value of the home currency would increase profits for foreign investors as a result of lower prices for imports and higher returns, hence affecting FDI inflow positively. The negative relationship between currency exchange rate and FDI inflow is also verified, asserting that depreciation of a country's home currency can reduce the investment cost for foreign investors, hence increasing FDI inflow (Lily et al., 2014; Sazanami et al., 2003; Udomkerdmongkol et al., 2009). For trade openness, its positive impact on FDI inflow is confirmed by Balakrishnan et al. (2013), Cleeve et al. (2015), Hasli et al. (2015), and Oloyede and Kolapo (2018). The positive nexus between domestic investment, economic growth, and FDI inflow is additionally documented by several studies (see Ramirez \& Mordecki [2014] for Uruguay, Ugochukwu \& Chinyere [2013] and Ikechi \& Anayochukwu [2014] for Nigeria, Shuaib \& Ndidi [2015] for the Middle East and North Africa countries, and Meyer \& Sanusi [2019] for South Africa).

For the causality association between FDI and economic growth, a general understanding is evident for the assenting contribution of FDI inflow toward stimulating the long (short) terms of economic growth; however, the type of causal relationship between the two macrovariables remains a debatable issue. As per the literature, we find five strands of results on the FDI-growth nexus. First is a causal relationship from FDI to economic growth, which demonstrates that FDI provides externalities in the form of technology transfer and business know-how to the host developing countries, augmenting domestic savings and capital accumulation, earning foreign exchange, and importing positive spillover to the host economy, in addition to the educational, technological, as well as the infrastructure developments in conjunction with labor efficiency enhancements and human capital developments. Presumably, the overall externalities would create the opportunity to have an extensive spillover effect for the whole economy, boosting its overall productivity, implying that the crowd-in effect is higher than the crowd-out effect, and hence stimulating the country's economic growth rates through knowledge spillover and market efficiency improvements (Abdouli \& Hammami, 2017; Chan et al., 2014; Dinh et al., 2019; Pegkas, 2015; Prabhakar et al., 2015; Samantha \& Haiyun, 2017; Uwubanmwen \& Ogiemudia, 2016). Second is a causal relationship from economic growth to FDI that counts economic growth as a determining factor of FDI where a country's higher growth rates would indicate its desirability, hence providing conductive economic attributes for FDI inflow (Yormirzoev, 2015; Zhang, 2001) for the states of Central and Eastern Europe (CEE) alongside the Commonwealth of Independent States; see Hlavacek and Bal-Domanska (2016) for the attributes for the CEE states alone.

Third is the conditional effect argument whereby FDI may or may not have an impact on economic growth; however, the impact is subject to certain economic, market, or social conditions that should be met in the host economy. The conditional view calls for predetermined conditions to be available as a prerequisite for gaining benefits from FDI-positive externalities, leading to economic growth stimulation (Note 3). Balasubramanyam et al. (1996) concluded that FDI inflows enhance growth in export-oriented countries but not in import-substituting countries; de Mello (1997) found that FDI would have a significant positive effect on growth for economies with high income, while Borensztein et al. (1998) identified that economies' labor forces need to have attained a certain educational standard to have positive contributions of FDI inflow toward economic growth. Others have concluded that only economies with well-developed financial markets would have a significant contribution of FDI inflow toward growth stimulation (Alfaro et al., 2004; Durham, 2004; Hermes \& Lensink, 2003). Agrawal (2015), Alfaro et al. (2010), Ranjan and Agrawal (2011), and Silajdzic and Mehic (2016) argued that FDI impact on economic growth is subject to the country-specific situation. Procázka et al. (2015) identified the negative contribution of corruption level on FDI inflows. For 22 sub-Saharan African countries, Adams and Opoku (2015) identified that the growth effect of FDI is stimulated in the presence of effective and quality regulations, namely credit market regulations, business regulations, and labor market regulations; otherwise, FDI would not have an independent significant effect on growth. On a sample of developed and developing countries, Makiela and Ouattara (2018) conclusively revealed that FDI affects growth via inputs accumulation, reflecting that factors other than FDI may have contributed to the increase in growth.

Fourth, a bidirectional relationship between the two macrovariables was concluded by Hansen and Rand (2006) and Liu et al. (2009). Fifth, a neutral relationship between FDI and economic growth was revealed by Zhang (2001), who confirmed the neutral or nonuniform pattern of direction between growth and FDI in the context between East Asia and Latin America. On a panel of four Asian countries over the period 1960-2017, India, Bangladesh, Sri Lanka, and Pakistan, Kathuria (2019) revealed that the relationship between FDI and growth is not uniform and that FDI has not resulted in long-term growth in any of the selected countries. 


\section{Methodology}

\subsection{Data and Proxies of Variables}

On a single economy basis, in this paper we adopt a time series (panel) analysis to test for a dataset on the BRICS countries as fast-growing emerging economies. Our test covers 38 years (1981-2018) with a total of 190 panel data points. The dataset used was extracted from the World Bank's World Development Indicators and the IMF's International Financial Statistics (Note 4). The ratio of net foreign direct investment inflow percentage of GDP was used to proxy the FDI inflow variable (FDIF), while the economic growth rate was measured by GDP annual growth (GDPG). We argue that an economy with growth prospects would afford better profit alternatives and higher savings rates for FDI providers, assuming that FDI positive externalities and technology spillover are subject to the economic attractiveness and absorbing capacity of the host economy, resulting in a positive impact of economic growth on FDI inflow.

The real exchange rate (FXRate) is defined as the annual nominal exchange rate (NER) of the home (domestic) currency vis-à-vis the U.S. dollar multiplied by the ratio of the price level in the U.S. to the price level of the home (domestic) currency. Following Osinubi and Amaghionyeodiwe (2009) and Lily et al. (2014), in our measure we used the purchasing power parity method (PPP) whereby the NER is adjusted for the price differential by keeping the U.S. consumer price index in the numerator and the host country's consumer price index in the denominator, hence making the nominal exchange rate real. The level of trade openness (ImpExp), as measured by the ratio of exports of goods and services and imports of goods and services as percentage of GDP, is used as a policy variable to consider the benefits of outward-oriented trade strategies adopted by the host economy, counting in turn for the country's trade openness. Though countries differ significantly in terms of natural resources availability, labor force skills, level of per capita income, and other country-specific conditions, we argue that trade openness as indicated by level of exports and imports would generate a positive impact on FDI inflow. The domestic investment variable is proxied by gross fixed capital formation (GFGF) as percentage of GDP. The GFGF variable is counted as an indicator of the economy's overall investment advancements, which is replicated positively to attract more FDI inflow to the host country, implying a significant complementary relationship between domestic investment and FDI inflow. Table 1 summarizes variables definition and the proxies used.

Table 1. Variables Definition and Measurement

\begin{tabular}{c|c}
\hline VARIABLE OF THE STUDY & MEASUREMENT \\
\hline FOREIGN DIRECT INVESTMENT & The ratio of net foreign direct investment inflow as percentage \\
INFLOW (FDIF) & of GDP \\
GROSS DOMESTIC PRODUCT \\
GROWTH RATE (GDPG)
\end{tabular}

\subsection{Model Specification}

The following models have been used to test for the relationship between FDIF and GDPG along with the proposed influential variables:

$$
F D I F_{t}=\beta_{0}+\beta_{1} \mathrm{GDPG}_{\mathrm{t}}+\beta_{2} \text { FX Rate }_{t}+\beta_{3} \operatorname{ImpExp}_{t}+\beta_{4} G F C F_{t}+\varepsilon_{t}
$$

Where FDIF, GDPG, FX Rate, ImpExp, and GFCF are foreign direct investment inflow, gross domestic product growth, foreign exchange rate, import and export, and gross fixed capital formation, respectively. $\varepsilon_{t}$ is the disturbance term, which is assumed to be normally distributed. $\beta_{0}$ is the model intercept, $\beta_{1}, \ldots, \beta_{4}$ are the coefficients of GDPG, FXRate, ImpExp, and GFCF respectively. 
Because model 1 represented the relationship of time series (panel) data, it was necessary to test the stationary condition of all variables included in the model. The stationary condition of the modeled variables was tested using ADF (Dickey \& Fuller, 1979) and Phillips-Perron (PP) (Phillips \& Perron, 1988). As illustrated by Table 3 , only two variables were $\mathrm{I}(0)$ level stationary, and the remaining variables were $\mathrm{I}(1)$ (first-differenced). For the ARDL bound test (Pesaran et al., 2001) model variables, which were stationary at different lags (I[0] and I[1]), we tested their cointegration. This is not the only advantage of ARDL model; it has several advantages over traditional methods. Beside the estimation of the short and long run of relationships among variables, it takes into account the endogeneity problem by adding different lags of the dependent and independent variables to the model. The long-run relationship of FDIF with all variables in model (1) using the ARDL bound approach can be written as:

$$
\begin{aligned}
\text { FDIF }_{t}=\beta_{01}+ & \sum_{i=1}^{n 1} \gamma_{i} F D I F_{t-i}+\sum_{i=0}^{n 2} \beta_{11 i} G D P G_{t-i}+\sum_{i=0}^{n 3} \beta_{21 i} \text { FXRate }_{t-i}+\sum_{i=0}^{n 4} \beta_{31 i} \text { ImpExp }_{t-i} \\
& +\sum_{i=0}^{n 5} \beta_{41 i} G F C F_{t-i}+\varepsilon_{t 1}
\end{aligned}
$$

Where $n_{1}, \ldots, n_{5}$ are the optimal numbers of optimal lags for each variable automatically identified by ARDL bound approach using Eviews11. The function also supports automatic identification of the best model with different numbers of lags according to different selection criteria (Akaike [1994] Information Criteria [AIC] and Bayesian Information Criterion (BIC). It also provides tools to visualize the cointegration (long-term) relation and test it using the bound test procedure. The ARDL bound approach tests for cointegration among variables in model 2 (Pesaran et al., 2001). It produces F-statistics along with lower and upper critical values at three different significance levels $(1 \%, 5 \%$, and $10 \%)$.

The F-test statistics should be above the upper bound to reject the null hypothesis on no cointegration. The ARDL procedure then estimates the short-run model (based on model 1) using error correction model (ECM), which can be presented as follows:

$$
\begin{aligned}
\Delta F D I F_{t}=\beta_{0}+ & \sum_{i=1}^{n 1} \gamma_{i} \Delta F D I F_{t-i}+\sum_{i=0}^{n 2} \beta_{1 i} \Delta G D P G_{t-i}+\sum_{i=0}^{n 4} \beta_{3 i} \Delta F X R a t e_{t-i}+\sum_{i=0}^{n 5} \beta_{4 i} \Delta I m p E x p_{t-i} \\
& +\sum_{i=0}^{n 7} \beta_{6 i} \Delta G F C F_{t-i}+\lambda_{1} E C_{t-1}+\varepsilon_{t}
\end{aligned}
$$

Where $\Delta$ is the first difference, and $\lambda$ is the speed of adjustment parameter of error correction term lagged for one period $\left(E C_{t-1}\right)$ toward the long-run equilibrium.

Because the ARDL bound approach tests the relationship among variables using short- and long-run models 2 and 3 without specifying the direction of this relationship, we used Toda and Yamamoto's (1995) test to study the cause and effect between FFIF and GDPG. The Toda Yamamoto test has an advantage over the traditional Granger causality test because it considers nonstationary and cointegrated variables.

ADF and PP unit root tests (Asteriou \& Hall, 2007) were used to test the stationarity of all variables. Model diagnostic tests were used to check the assumption of the ARDL model. Assumptions including the normality and independence of residuals were checked by applying the Breusch-Godfrey and Ljung-Box tests for autocorrelation in residuals, and the heteroskedasticity was checked by applying the Breusch-Pagan-Godfrey test. Ramsey's RESET test was used for any model misspecification in the model. Stability of the coefficients was checked through the CUSUM and CUSUMSQ of recursive residuals (Bani-Mustafa et al., 2019; Brown et al., 1975).

\section{Data Description and Empirical Results}

\subsection{Descriptive Statistics}

Table 2 presents descriptive statistics for the variables included in this paper for the five BRICS countries over the period of 38 years (1981-2018). As illustrated in Table 2, the overall average FDIF for all countries is 1.62 with relatively high standard deviation, compared to the mean, of 1.53 with a minimum of -0.77 and a maximum of 6.2. Figure 1 shows the average of FDIF for all BRICS countries over the same period of study (1981-2018). FDIF overall behavior over time was increasing with a low value at the beginning until 1991 and started to increase thereafter (with some fluctuation) until 2008, at which point it started to decrease. 
Table 2. Descriptive Statistics of FDIF, GDPG, and Control Variables

\begin{tabular}{c|ccccccc}
\hline Variable & Country & $\boldsymbol{N}$ & Mean & StDev & Min & Median & Max \\
\hline \multirow{4}{*}{ FDIF by } & Brazil & 38 & 2.167 & 1.562 & 0.129 & 1.851 & 5.034 \\
Country & Russia & 38 & 1.337 & 1.265 & 0.175 & 0.967 & 4.503 \\
& India & 38 & 0.923 & 0.897 & 0.003 & 0.695 & 3.621 \\
& China & 38 & 2.743 & 1.694 & 0.21 & 2.933 & 6.187 \\
FDIF All & South Africa (SA) & 38 & 0.943 & 1.258 & -0.766 & 0.548 & 5.983 \\
& Total & $\mathbf{1 9 0}$ & $\mathbf{1 . 6 2 3}$ & $\mathbf{1 . 5 2 9}$ & $\mathbf{- 0 . 7 6 6}$ & $\mathbf{1 . 0 2 7}$ & $\mathbf{6 . 1 8 7}$ \\
& Brazil & 38 & 2.256 & 3.205 & -4.393 & 2.606 & 7.988 \\
GDPG by & Russia & 38 & 0.764 & 5.586 & -14.531 & 0.795 & 10 \\
Country & India & 38 & 6.158 & 1.916 & 1.057 & 6.285 & 9.628 \\
& China & 38 & 9.557 & 2.75 & 3.907 & 9.347 & 15.139 \\
GDPG All & South Africa (SA) & 38 & 2.165 & 2.176 & -2.137 & 2.443 & 5.604 \\
ImportExp & Total & $\mathbf{1 9 0}$ & $\mathbf{4 . 1 8}$ & $\mathbf{4 . 6 6 4}$ & $\mathbf{- 1 4 . 5 3 1}$ & $\mathbf{4 . 3}$ & $\mathbf{1 5 . 1 3 9}$ \\
GFCF & & 190 & 19.233 & 8.274 & 6.11 & 19.193 & 55.289 \\
FXRate & & 190 & 25.023 & 7.708 & 14.387 & 22.32 & 45.69 \\
\hline
\end{tabular}

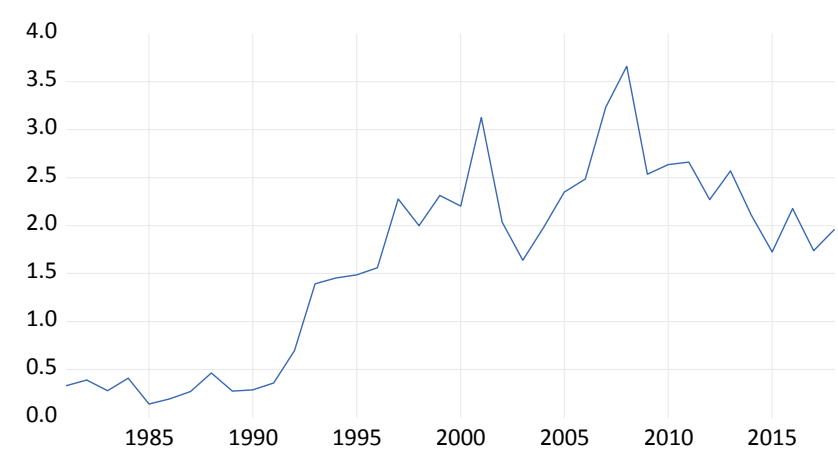

Figure 1. Trend graph of FDIF during 1981-2018

As per Table 2, minimum FDIF means are for India and South Africa, with almost the same mean at 0.92 (SD $=$ $0.9)$ and $0.94(\mathrm{SD}=1.26)$, with more variation for South Africa. The highest FDIF mean is for China (2.74; SD $=1.69)$, followed by Brazil with a mean of $2.17(\mathrm{SD}=1.56)$. The general pattern of FDIF over time is almost the same for all countries, starting with low values of FDIF before starting to increase and finishing at the end of the study period with a decline, except for Brazil, which maintained the same level after the increase as illustrated in Figure 2. 


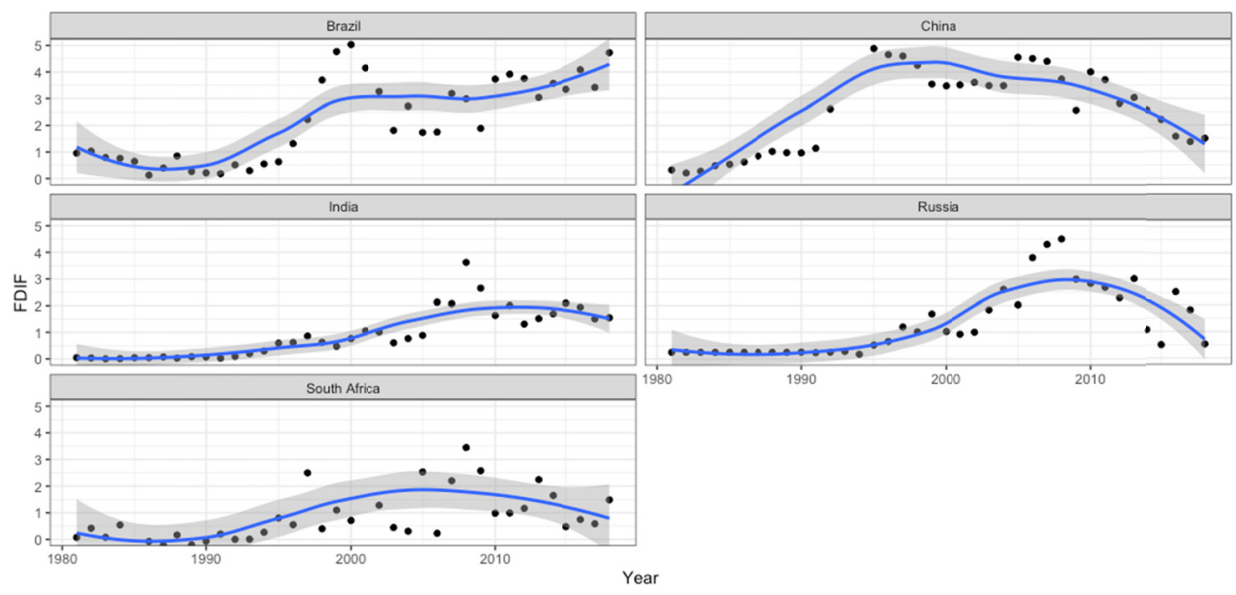

Figure 2. Trend graph of FDIF by country

Table 2 also presents a summary of GDP growth for BRICS countries over the same period (1981-2018). Average GDP growth for all BRICS countries is 4.18 with relatively high standard deviation of 4.66. The GDP growth fluctuated over the study period of 1981-2018, with a maximum GDP growth average in 2007 and a minimum in 2009 (perhaps as a result of the financial crisis in 2008). The highest GDP growth was for China with an average of $9.55(\mathrm{SD}=2.75)$, followed by India with an average of $6.16(\mathrm{SD}=2.75)$. The lowest country in terms of GDP growth was Russia with an average of $0.764(\mathrm{SD}=5.59)$. The trend graphs (Figure 4) for GDPG by country show that the greatest volatility in GDPG was in Russia and China.

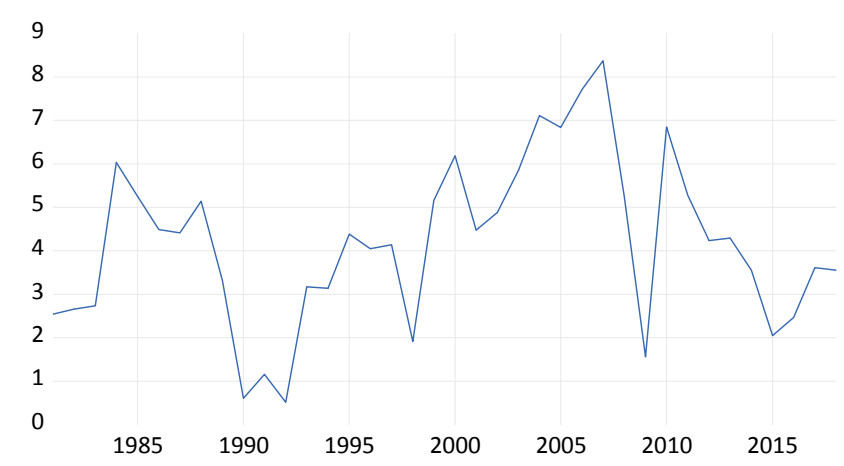

Figure 3. Trend graph for the mean of GDPG during 1981-2018

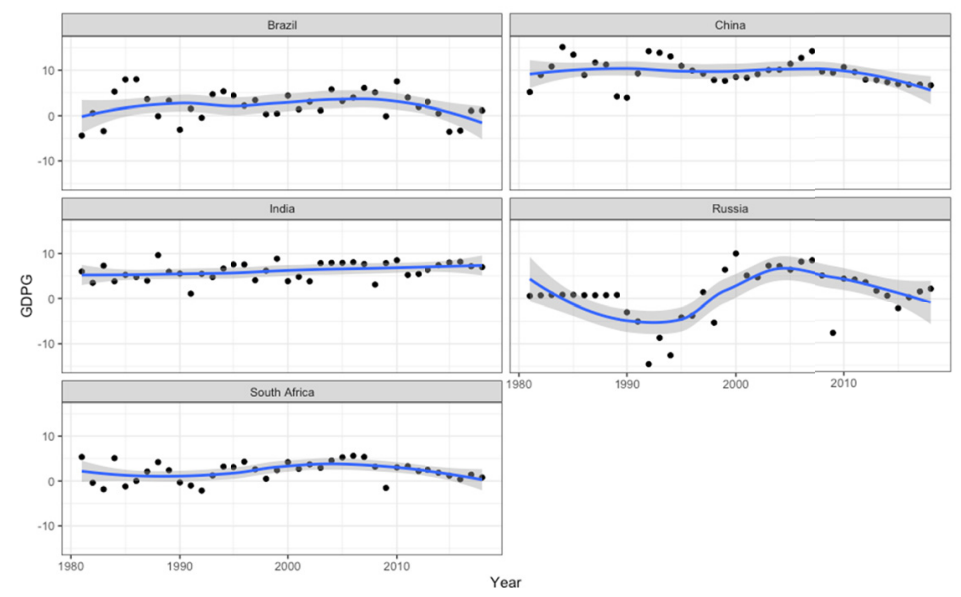

Figure 4. Trend graphs of GDPG by country 


\subsection{Empirical Results}

\subsubsection{Unit Root Test}

Table 3 summarizes the results of unit root test for all variables using ADF and PP tests. As illustrated by both tests, all variables are either $\mathrm{I}(0)$ or $\mathrm{I}(1)$ and none are $\mathrm{I}(2)$, which is essential to be checked before applying ARDL. As argued by Ranco et al. (2015), ARDL results would be biased if any variables were stationary at level $\mathrm{I}(2)$.

Table 3. ADF and PP Unit Root Test

\begin{tabular}{|c|c|c|c|c|c|}
\hline \multirow[b]{3}{*}{ Variables } & \multicolumn{2}{|c|}{ Augmented Dickey-Fuller test } & \multicolumn{2}{|c|}{ Phillips-Perron test } & \multirow{3}{*}{$\begin{array}{c}\text { Order of } \\
\text { Integration }\end{array}$} \\
\hline & Level & First Difference & Level & First Difference & \\
\hline & T-value & T-value & T-value & T-value & \\
\hline FDIF & $-1.77 * *$ & $-9.66^{* * *}$ & $-1.55^{*}$ & $-9.11 * * *$ & $\mathrm{I}(0)$ \\
\hline GDPG & $-6.4 * * *$ & $-11.69 * * *$ & $-6.16^{* * *}$ & $-10.77 * * *$ & $\mathrm{I}(0)$ \\
\hline FXRate & -0.92 & $-7.83 * * *$ & 0.64 & $-7.95 * * *$ & $\mathrm{I}(1)$ \\
\hline ImportExp & -0.83 & $-8.9 * * *$ & -0.9 & $-9.56^{* * *}$ & $\mathrm{I}(1)$ \\
\hline GFCF & $-3.68 * * *$ & $-7.56 * * *$ & $-1.29 *$ & $-8.54 * * *$ & $\mathrm{I}(0)$ \\
\hline
\end{tabular}

Note: $*$ is significant at $10 \%$ level, $* *$ at $5 \%$ level, and $* * *$ at $1 \%$ level.

\subsubsection{ARDL Bounds Test (BRICS Countries)}

The ARDL model is fitted Eviews11, which chooses the optimal number of lags for all variables, based on AIC. The F-statistics for the ARDL bounds test to test for the cointegration of model variables is 3.99, which is higher than $\mathrm{I}(0)$ and $\mathrm{I}(1)$ at $5 \%$ level of alpha, as illustrated in Table 4. This means that FDIF is cointegrated with selected variables in our model over the period of study (1981-2018) at 5\% level of significance.

Table 4. Cointegration Test Results

\begin{tabular}{c|cccc}
\hline Wald F-Statistics & Level & Lower Bound I(0) & Upper Bound I(1) & Outcome \\
\hline \multirow{3}{*}{3.99} & $1 \%$ & 3.29 & 4.37 & \\
& $5 \%$ & 2.56 & 3.49 & Cointegrated \\
& $10 \%$ & 2.20 & 3.09 & \\
\hline
\end{tabular}

\subsubsection{Short-Run Estimates (BRICS Countries)}

Short-run estimates of our ARDL model (3) are illustrated in Table 5. The results revealed that only the fourth-lag FDIF was significantly positive in itself. Import and export has a positive and significant impact on FDIF in the short run. GDPG, FXRate, and GFCF show a positive but insignificant effect on FDIF in the short run. Error correction model is negative (as expected) and significant at $1 \%$ level. The coefficient of $E C T$ is -0.2245 , which represents the annual speed $(22.45 \%)$ of convergence toward equilibrium.

Table 5. Short-Run Coefficient of Short-Run ARDL Model (3)

\begin{tabular}{c|ccc}
\hline Variable & Estimate & Std.Err & $p$-value \\
\hline D(FDIF $(-1))$ & -0.102 & 0.074 & 0.1688 \\
$D($ FDIF $(-2))$ & 0.011 & 0.074 & 0.8838 \\
$D($ FDIF $(-3))$ & -0.055 & 0.073 & 0.4492 \\
D(FDIF $(-4))$ & 0.228 & 0.070 & 0.0012 \\
D(IMPORTEXP $)$ & 0.0415 & 0.016 & 0.0084 \\
D(FXRATE $)$ & $6.67 \mathrm{E}-05$ & 0.000156 & 0.6699 \\
ECT $(-1)$ & -0.2245 & 0.0453 & 0.0000 \\
\hline
\end{tabular}

4.1.2.2 Long-Run Estimates (BRICS Countries)

The main objective of this paper is centered on the long-run relationship between FDIF and GDP growth and the direction of cause and effect between these variables. The results of the long-run estimates are illustrated in Table 6, revealing that GDP growth is positive and the only significant factor with FDIF in the long run. The 
coefficient of DGPG is 0.23 , which means that an increase of $1 \%$ in GDPG will lead to a $0.23 \%$ increase in FDIF. Import and export is not significant to FIDF in the long run but showed a positive and significant effect on FDIF in the short run. FXrate and GFCF are positive but insignificant in both the short- and long-run models.

Table 6. Long-Run Coefficient of Short-Run ARDL Model (2)

\begin{tabular}{|c|c|c|c|}
\hline Variable & Estimate & Std.Err & p-value \\
\hline Intercept & 0.783 & 1.22 & 0.52 \\
\hline$G D P G$ & 0.2333 & 0.0857 & 0.0072 \\
\hline IMPORTEXP & 0.0456 & 0.0381 & 0.2333 \\
\hline$G F C F$ & -0.0333 & 0.0484 & 0.4918 \\
\hline FXRATE & -0.00086 & 0.00077 & 0.2655 \\
\hline \multicolumn{4}{|c|}{ Diagnostics Tests } \\
\hline \multicolumn{2}{|c|}{$R$-squared } & \multicolumn{2}{|l|}{0.692} \\
\hline \multicolumn{2}{|c|}{ Adjusted R-squared } & \multicolumn{2}{|l|}{0.672} \\
\hline \multicolumn{2}{|c|}{ Breusch-Godfrey test LM test } & $0.604(0.548)$ & No serial correlation \\
\hline \multicolumn{2}{|c|}{ Ramsey's RESET test for model specification } & $0.68 \quad(0.498)$ & Model is properly specified \\
\hline \multicolumn{2}{|c|}{ Breusch-Pagan test for homoskedasticity } & $1.28(0.242)$ & No heteroscedasticity \\
\hline
\end{tabular}

Table 6 also includes different diagnostic tests for our ARDL model. We used Breusch-Godfrey test to assess the presence of serial correlation in the model. Because the p-value $(0.76)$ is more than the significance level alpha $=$ 0.05, there is no evidence of serial correlation in the model. We also used Ramsey's RESET test for any model misspecifications. This tests if there is a need to include nonlinear combinations of the predicted variables in the model. We concluded that the model was properly specific because the p-value (0.498) was more than the significance level (5\%). We deployed the Breusch-Pagan test for the homoskedasticity (constant variance); because p-value (0.242) was more than the significance level $(5 \%)$, there was no violation in the homoskedasticity assumption. Despite the normality test having a value less than 5\%, Figure 5 shows the symmetry of the residuals. In general, regression modeling is robust to normality but not homogeneity of variance (Box, 1953).

Finally, we generated CUSUM and CUSUMSQ graphs (Figure 6) to check the stability of the parameters at 5\% level of significance (red lines). The plots generally show that the long-run coefficients were stable and within $5 \%$ boundaries, except for CUSUMSQ, which captured a sudden shift in parameters at the beginning but returned to stability (in the long run) within 5\% limits. This is evidence of structural change in the data, which may have been caused by fitting all BRICS countries together. Thus, it may be more appropriate to model each country alone or similar for all BRICS countries together, which we will cover later in this article.

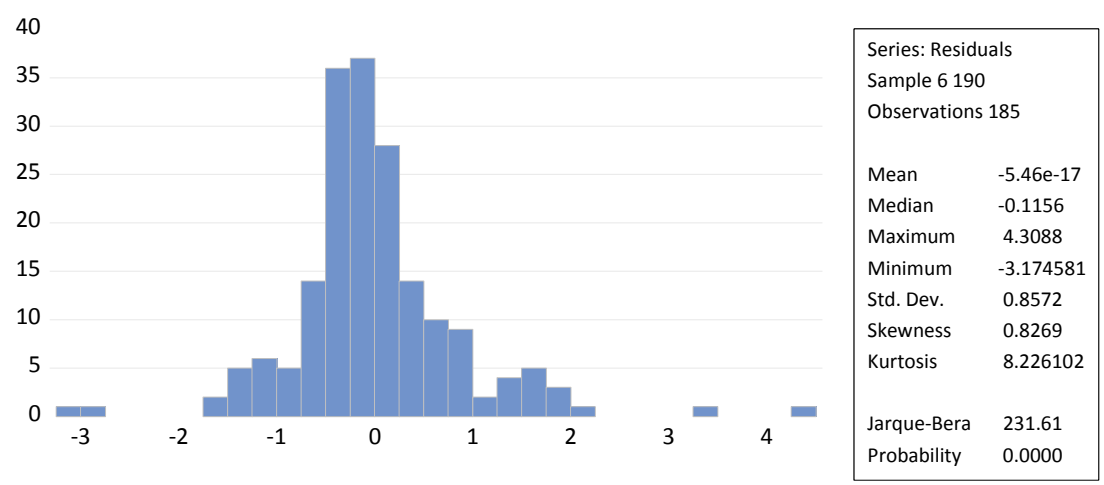

Figure 5. ARDL model residuals 

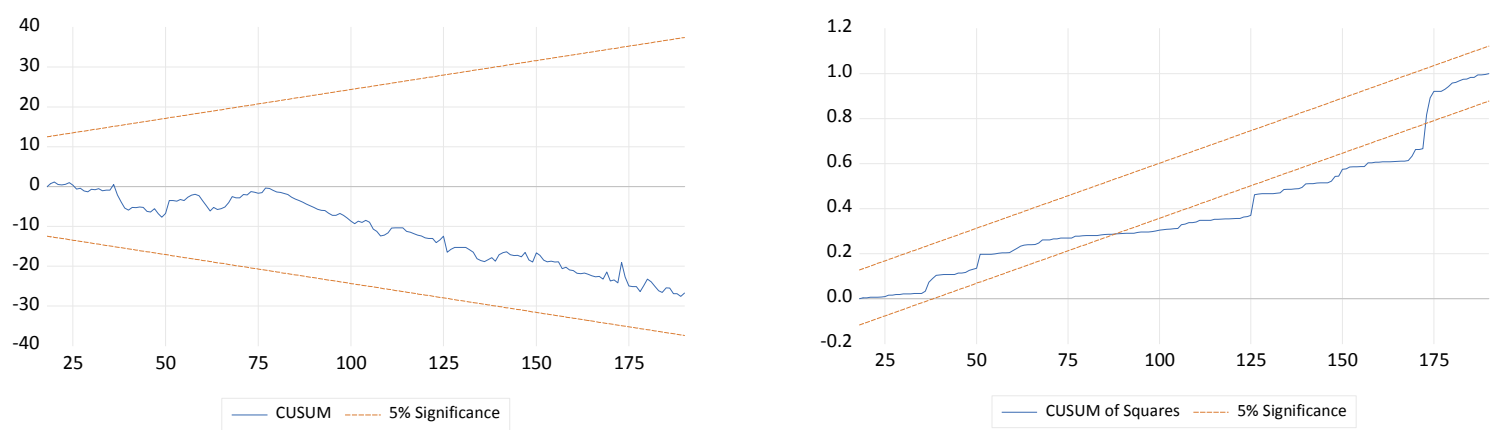

Figure 6. CUSUM and CUSUMSQ graphs

\subsubsection{Toda Yamamoto Causality Test (BRICS Countries)}

After estimating the long-run relationship between FDIF and GDPG using ARDL model for all BRICS countries, we used Toda Yamamoto causality test (Toda \& Yamamoto, 1995) to test if FDIF Granger causes GDPG. Because our variables were I(1), we used first-order difference with optimal number of lags. Numbers of lag order of Vector Autoregression (VAR) are determined based on several selection criteria such as AIC, Schwarz information criterion, final prediction error, and Hannan-Quinn information criterion. Toda Yamamoto Granger causality tests results are illustrated in Table 7. The estimates of VAR Granger causality WALD test are based on chi-square test statistics with 2 degrees of freedom (in accordance with appropriate lag length) along with their associated p-values. The result reveals a significant and unidirectional causality following from GDPG to FDIF.

Table 7. Toda Yamamoto Causality Test

\begin{tabular}{ccccc}
\hline Independent Variable & Response & Chi-Square & Df & p-value \\
\hline$G D P G \rightarrow$ & FDIF & 6.48 & 2 & 0.039 \\
$F D I F \rightarrow$ & GDPG & 28.54 & 2 & 0.75 \\
\hline
\end{tabular}

\subsubsection{ARDL Bound Test (Single-Country Level)}

The F-statistics for the ARDL bound test to test for the cointegration of our main model for each of the BRICS countries are illustrated in Table 8 . This means that FDIF is cointegrated with selected variables in our model over the period of study (1981-2018) at 5\% level of significance.

Table 8. Cointegration Test Results (BRICS-Single-Country Level)

\begin{tabular}{c|ccccc}
\hline Country & Wald F-Statistics & Outcome & Level & $\begin{array}{c}\text { Lower } \\
\text { Bound I(0) }\end{array}$ & $\begin{array}{c}\text { Upper } \\
\text { Bound I(1) }\end{array}$ \\
\hline Brazil & 3.58 & Cointegrated & $10 \%$ & 2.2 & 3.09 \\
Russia & 16.13 & Cointegrated & $5 \%$ & 2.56 & 3.49 \\
India & 4.44 & Cointegrated & $1 \%$ & 3.29 & 4.37 \\
China & 5.82 & Cointegrated & & & \\
South Africa & 6.53 & Cointegrated & & & \\
\hline
\end{tabular}

The results reveal that all countries are significant at level of 1\%, except Brazil, which is still significant but at a $5 \%$ level of significance.

\subsubsection{Short-Run Estimates (Single-Country Level)}

Table 9 indicates short-run implications. FDIF is found to have a significant lagged impact on itself in all countries with small differences in some countries in the lag number. GDPG also has a significant lagged impact on itself with the least number of lags in the case of South Africa, as illustrated in Table 9. The other three control variables' (import and exports, GFCF, FXRate) lags also found to have a significant impact on FDIF with slight differences among countries. 
Table 9. Short-Run Coefficient of ARDL Model (3) at Single-Country Level

\begin{tabular}{|c|c|c|c|c|c|}
\hline Variable & Brazil & Russia & India & China & South Africa \\
\hline$D(F D I F(-1))$ & $-1.71(0.12)^{* * *}$ & $0.26(0.12)^{* *}$ & $1.62(0.3)^{* *}$ & $-0.28(0.13)^{*}$ & $0.13(0.17)$ \\
\hline$D(F D I F(-2))$ & $-2.58(0.24)^{* * *}$ & $0.26(0.24)^{* *}$ & $2.11(0.24)^{* * *}$ & $0.44(0.14)^{* *}$ & $\begin{array}{c}-0.57 \\
(0.13)^{* * *}\end{array}$ \\
\hline$D(F D I F(-3))$ & $-2.75(0.23)^{* * *}$ & $-0.59(0.23) * * *$ & $-0.11(0.14)$ & $0.1(0.1)$ & $\begin{array}{c}-0.54 \\
(0.14)^{* * *}\end{array}$ \\
\hline$D(F D I F(-4))$ & $-2.12(0.27)^{* * *}$ & $-0.28(0.27)^{* *}$ & $0.5(0.22)$ & $0.23(0.09)^{*}$ & -- \\
\hline$D(F D I F(-5))$ & $-1.12(0.19)^{* * *}$ & $1.09(0.19)^{* * *}$ & $1.5(0.23)^{* * *}$ & $0.5(0.12)^{* *}$ & \\
\hline$D(G D P G)$ & $-0.47(0.12)^{* *}$ & $-0.01(0.12)$ & $0.01(0.02)$ & $0.68(0.09)^{* * *}$ & $0.01(0.09)$ \\
\hline$D(G D P G(-1))$ & $0.27(0.1)^{*}$ & $-0.53(0.1)^{* * *}$ & $-0.93(0.13)^{* * *}$ & $\begin{array}{c}-0.36 \\
(0.07)^{* * *}\end{array}$ & $\begin{array}{c}-0.67 \\
(0.17)^{* * *}\end{array}$ \\
\hline$D(G D P G(-2))$ & $0.73(0.13)^{* * *}$ & $-0.5(0.13)^{* * *}$ & $-0.79(0.11)^{* * *}$ & $-0.25(0.08)^{* *}$ & $-0.16(0.12)$ \\
\hline$D(G D P G(-3))$ & $0.26(0.1)^{*}$ & $-0.35(0.1)^{* * *}$ & $-0.64(0.09)^{* * *}$ & $\begin{array}{c}-0.35 \\
(0.07)^{* * *}\end{array}$ & $-0.12(0.07)$ \\
\hline$D(G D P G(-4))$ & $-0.27(0.06)^{* *}$ & $-0.28(0.06)^{* * *}$ & $-0.52(0.07)^{* * *}$ & $-0.53(0.1)^{* * *}$ & -- \\
\hline$D(G D P G(-5))$ & -- & $-0.18(0.12)^{* * *}$ & $-0.16(0.03)^{* *}$ & $0.24(0.06)^{* *}$ & -- \\
\hline$D(I M P O R T E X P)$ & $-0.16(0.12)$ & $-0.13(0.13) * * *$ & $0.07(0.03)$ & $-0.06(0.07)$ & $\begin{array}{c}-3.22 \\
(0.64)^{* * *}\end{array}$ \\
\hline$D(I M P E X P(-1))$ & $1.04(0.13)^{* * *}$ & $0.1(0.06)^{* * *}$ & $0.04(0.04)$ & $-0.4(0.07)^{* * *}$ & $\begin{array}{c}2.48 \\
(0.72)^{* * *}\end{array}$ \\
\hline$D(I M P E X P(-2))$ & $0.42(0.06)^{* * *}$ & $0.01(0.07)$ & $-0.24(0.04)^{* *}$ & $-0.42(0.1)^{* *}$ & $\begin{array}{c}-1.12 \\
(0.46)^{* *}\end{array}$ \\
\hline$D(I M P T E X P(-3))$ & $0.52(0.07)^{* * *}$ & $-0.12(0.09) * * *$ & $0.25(0.04)^{* *}$ & $0.09(0.07)$ & $\begin{array}{c}0.42 \\
(0.06)^{* * *}\end{array}$ \\
\hline$D(I M P E X P(-4))$ & $0.61(0.09)^{* * *}$ & $-0.08(0.06) * * *$ & $-0.01(0.04)$ & $\begin{array}{c}-0.62 \\
(0.07)^{* * *}\end{array}$ & -- \\
\hline$D(I M P E X P(-5))$ & $0.11(0.06)$ & $-0.04(0.11)^{* *}$ & $-0.43(0.06) * * *$ & $\begin{array}{c}-0.78 \\
(0.12)^{* * *}\end{array}$ & -- \\
\hline$D(G F C F)$ & $-0.62(0.11)^{* * *}$ & $-0.03(0.13)$ & $-0.14(0.04)^{* *}$ & $\begin{array}{c}0.0006 \\
(0.0002)^{* *}\end{array}$ & $\begin{array}{c}-0.88 \\
(0.16)^{* * *}\end{array}$ \\
\hline$D(G F C F(-1))$ & $-0.67(0.13)^{* * *}$ & $0.25(0.12)^{* * *}$ & $0.26(0.05)^{* *}$ & $\begin{array}{c}-0.0059 \\
(0.0007)^{* * *}\end{array}$ & $\begin{array}{c}-0.52 \\
(0.13)^{* * *}\end{array}$ \\
\hline$D(G F C F(-2))$ & $-0.06(0.12)$ & $-0.42(0.16)^{* * *}$ & $0.2(0.06)^{* *}$ & $\begin{array}{c}-0.0047 \\
(0.0006)^{* * *}\end{array}$ & $\begin{array}{c}-0.5 \\
(0.13)^{* * *}\end{array}$ \\
\hline$D(G F C F(-3))$ & $1.2(0.16)^{* * *}$ & $-0.36(0.11)^{* *}$ & $0.8(0.11)^{* * *}$ & $\begin{array}{c}-0.0024 \\
(0.0003)^{* * *}\end{array}$ & -- \\
\hline$D(G F C F(-4))$ & $-0.58(0.11)^{* * *}$ & $-0.45(0.12)^{* * *}$ & $0.69(0.11)^{* * *}$ & $\begin{array}{c}-0.0007 \\
(0.0002)^{*}\end{array}$ & -- \\
\hline$D(G F C F(-5))$ & $0.76(0.12)^{* * *}$ & $-0.44(0.0009)^{* * *}$ & $0.57(0.08)^{* * *}$ & $\begin{array}{c}0.001 \\
(0.0002)^{* * *}\end{array}$ & -- \\
\hline$D(F X R A T E)$ & $-0.007(0.0009) * * *$ & $-0.0002(0.0005)$ & $0.11(0.02)^{* *}$ & $\begin{array}{c}-0.309 \\
(0.047)^{* * *}\end{array}$ & $\begin{array}{c}0.002 \\
(0.001)^{* * *}\end{array}$ \\
\hline$D(F X R A T E(-1))$ & $0.005(0.0005)^{* * *}$ & $0.002(0.0008)^{* * *}$ & $-0.03(0.02)$ & $\begin{array}{c}-0.005 \\
(0.0006)^{* *}\end{array}$ & $\begin{array}{c}-0.003 \\
(0.001)^{* * *}\end{array}$ \\
\hline$D(F X R A T E(-2))$ & $0.01(0.0008)^{* * *}$ & $0.002(0.0009) * * *$ & $-0.04(0.02)$ & $\begin{array}{c}-0.002 \\
(0.0003)\end{array}$ & $\begin{array}{c}-0.002 \\
(0.001)^{* * *}\end{array}$ \\
\hline$D(F X R A T E(-3))$ & $0.01(0.0009)^{* * *}$ & $0.001(0.0004)^{* *}$ & $-0.24(0.04) * * *$ & $\begin{array}{c}-0.001 \\
(0.0002)\end{array}$ & $\begin{array}{c}-0.002 \\
(0.001)^{* * *}\end{array}$ \\
\hline$D(F X R A T E(-4))$ & $0.002(0.0004)^{* * *}$ & $0.001(0.0007)^{* * *}$ & $-0.13(0.02)^{* * *}$ & $\begin{array}{c}0.001 \\
(0.0002)^{* *}\end{array}$ & -- \\
\hline$D(F X R A T E(-5))$ & $0.01(0.0007)^{* * *}$ & -- & $0.04(0.02)$ & -- & -- \\
\hline$E C T(-1)$ & $-0.34(0.054)^{* * *}$ & $-1.09(0.039)^{* * *}$ & $-1.63(0.22)^{* * *}$ & $\begin{array}{c}-0.26 \\
(0.03)^{* * *}\end{array}$ & $\begin{array}{c}-1.42 \\
(0.2)^{* * *}\end{array}$ \\
\hline
\end{tabular}

Note: $*$ is significant at $10 \%$ level, $* *$ at $5 \%$ level, and $* * *$ at $1 \%$ level. Standard errors are in parenthesis () 


\subsubsection{Long-Run Estimates at Single-Country Level}

The study is mainly centered on explaining the long-run relationship between FDIF and GDPG. The long-run coefficients of ARDL model 1 are illustrated in Table 10. All countries have a significant and positive effect of GDPG on FDIF, except Brazil. This significance is joined with the significance of trade openness (import and export), which means that all countries except Brazil have significant trade openness on FDIF.

Table 10. Long-Run Coefficient of ARDL Model (3) at Single-Country Level

\begin{tabular}{|c|c|c|c|c|c|}
\hline Variable & Brazil & Russia & India & China & South Africa \\
\hline$G D P G$ & $0.842(1.42)$ & $0.31(0.13)^{*}$ & $0.002(0.03)^{*}$ & $1.782(1)^{*}$ & $\begin{array}{c}0.96 \\
(0.3)^{* * *}\end{array}$ \\
\hline IMPORTEXP & $1.955(1.34)$ & $-0.37(0.1)^{* *}$ & $0.101(0.01)^{* * *}$ & $\begin{array}{c}-0.729 \\
(0.53)^{* * *}\end{array}$ & $-2.07(1.04)^{*}$ \\
\hline FXRATE & $0.43(0.96)$ & $-0.53(0.12)^{* *}$ & $\begin{array}{c}-0.0002 \\
(0.0001)^{* * *}\end{array}$ & $\begin{array}{c}0.0002 \\
(0.01)^{* * *}\end{array}$ & $\begin{array}{c}0.01 \\
(0.003)^{*}\end{array}$ \\
\hline$G F C F$ & $-0.158(0.14)$ & $\begin{array}{c}-0.003 \\
(0.001)^{* *}\end{array}$ & $0.03(0.02)$ & $0.71(0.45)$ & $\begin{array}{c}-0.23 \\
(0.07)^{* * *}\end{array}$ \\
\hline$C$ & $\begin{array}{l}-26.46 \\
(30.41)\end{array}$ & $22.66(5.38)^{* *}$ & $\begin{array}{c}-1.339 \\
(0.44)^{* * *}\end{array}$ & $\begin{array}{c}-26.3 \\
(14.5)^{* * *}\end{array}$ & $\begin{array}{c}28.79 \\
(14.05)^{*}\end{array}$ \\
\hline \multicolumn{6}{|l|}{ Diagnostics Tests } \\
\hline$R$-squared & 0.98 & 0.99 & 0.98 & 0.97 & 0.94 \\
\hline Adjusted R-squared & 0.93 & 0.94 & 0.93 & 0.88 & 0.86 \\
\hline Normality test using $J B$ & $1.63(0.44)$ & $0.82(0.66)$ & $1.03(0.597)$ & $3.4(0.18)$ & $0.44(0.801)$ \\
\hline $\begin{array}{c}\text { Breusch-Godfrey test LM } \\
\text { test }\end{array}$ & $0.601(0.56)$ & $0.83(0.55)$ & $2.194(0.43)$ & $1.92(0.34)$ & $1.49(0.401)$ \\
\hline $\begin{array}{c}\text { Ramsey's RESET test for } \\
\text { model specification }\end{array}$ & $0.50(0.62)$ & $2.55(0.084)$ & $1.12(0.29)$ & $1.4(0.26)$ & $0.49(0.66)$ \\
\hline $\begin{array}{c}\text { Breusch-Pagan test for } \\
\text { homoskedasticity }\end{array}$ & $2.8(0.101)$ & $0.67(0.77)$ & $0.284(0.97)$ & $0.36(0.96)$ & $0.60(0.60)$ \\
\hline
\end{tabular}

$* * *, * *$, and $*$ denote significance at $1 \%$ level, $5 \%$ level, and $10 \%$ level respectively. The value in parentheses is p-value for LM test, RESET test, and JB and BP tests.

Model checking and validity for all individual ARDL models are presented in the same table (10). The Ramsey's RESET test results indicate that the models do not suffer from the misspecification problem. Breusch-Godfrey (LM) tests reveal there is no serial correlation at 5\% significance level. Furthermore, all p-values of BP test are shown to be above the significance level of $5 \%$, meaning that there is no heteroscedasticity problem in our models. Normality was tested using Jarque-Bera test statistics, resulting in p-values more than the significance level (5\%) for all countries, as illustrated in Table 10.

Finally, stability of ARDL models for each country was tested using CUSUM and CUSUMSQ graphs (Figure 8). In the graphs, the stability of the parameters is checked by plotting the CUSUM and CUSUMSQ of recursive residuals. Parameters are stable as long as they are within 5\% level of significance (red lines). The plots in general show that the long-run coefficients are stable and within 5\% boundaries. 


\section{Brazil}
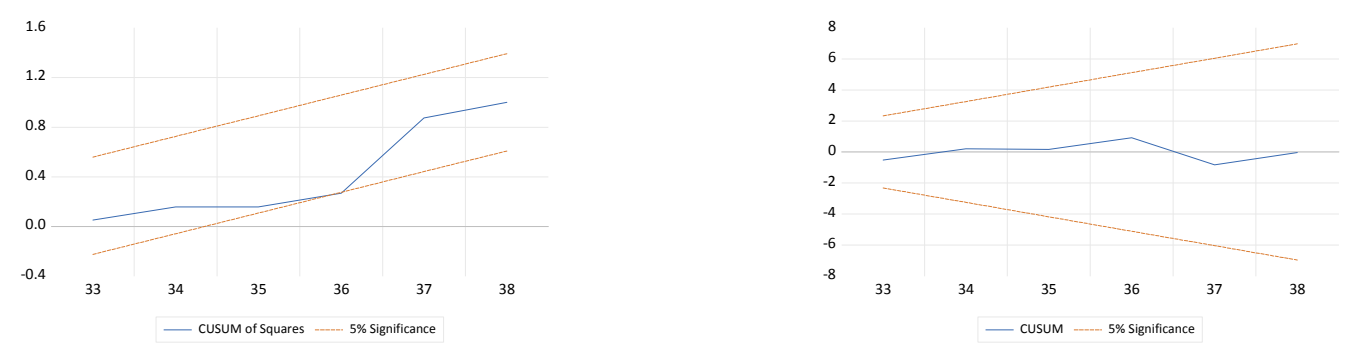

\section{Russia}
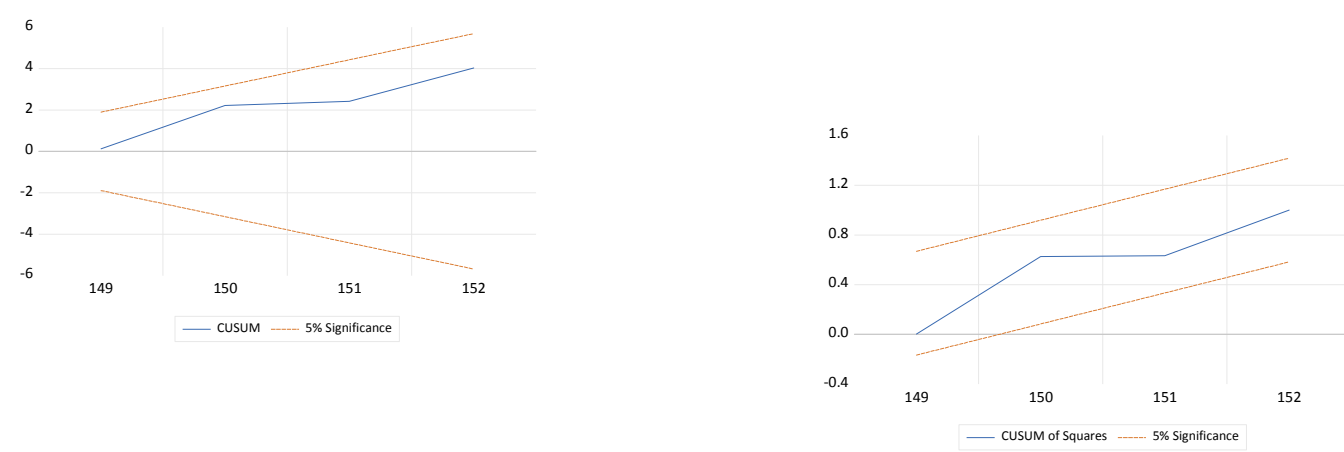

India
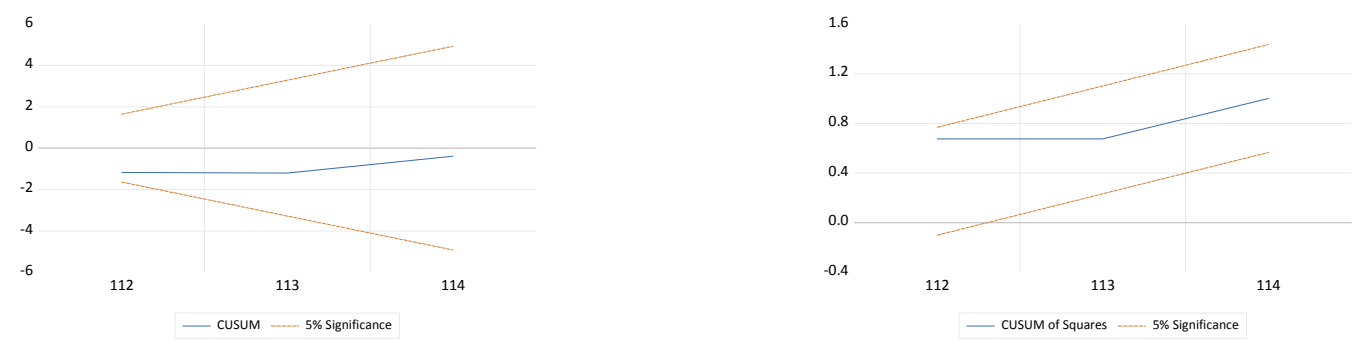

China
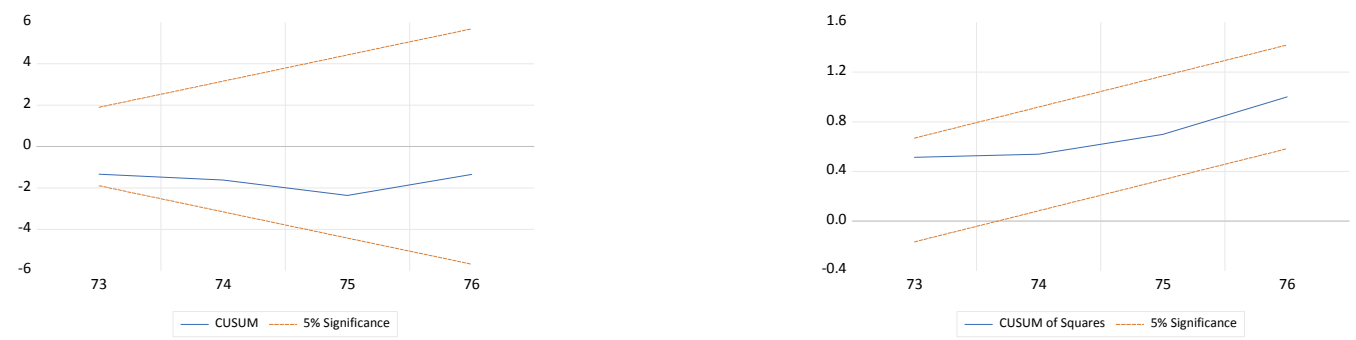

\section{South Africa}
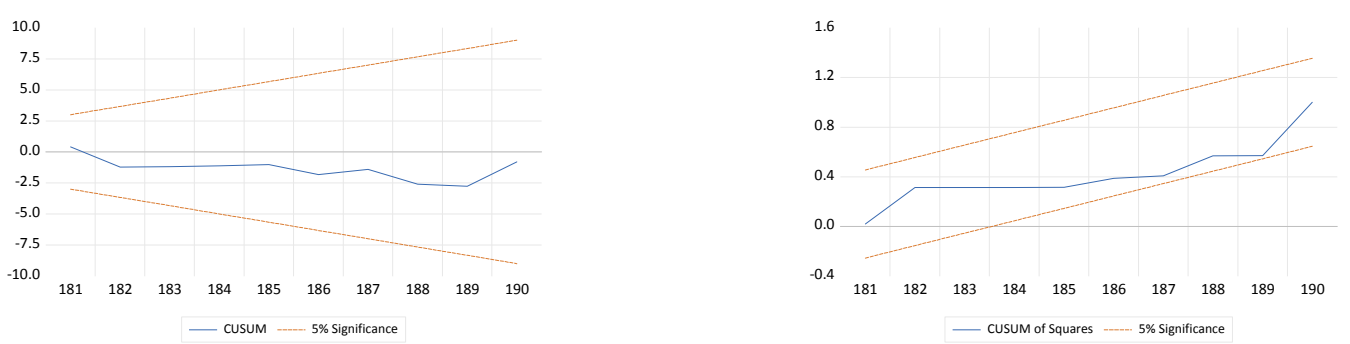

Figure 7. CUSUM and CUSUM of square tests 


\subsubsection{Toda Yamamoto Causality Test (Single-Country Level)}

After estimating the long-run relationship between FDIF and GDPG using ARDL models at the level of each of the BRICS countries, we used Toda Yamamoto causality test (Toda \& Yamamoto, 1995) to test if FDIF Granger caused GDPG. Toda and Yamamoto Granger causality test results are illustrated in Table 11. The estimates of VAR Granger causality WALD test is based on chi-square test statistics with 2 degrees of freedom along with their associated p-values. The results reveal a significant and unidirectional causality flowing from GDPG with FDIF at 5\% level of significance in India, China, and South Africa. Meanwhile there is a unidirectional causality flowing from FDIF with GDPG at 10\% level of significance for Brazil and Russia.

Table 11. Toda Yamamoto Causality Test at Single-Country Level

\begin{tabular}{|c|c|c|c|c|c|}
\hline Country & Independent Variable & Response & Chi-Square & $d f$ & $p$-value \\
\hline \multirow{2}{*}{ Brazil } & $G D P G \rightarrow$ & FDIF & 0.004 & 2 & 0.9979 \\
\hline & $F D I F \rightarrow$ & GDPG & 4.719 & 2 & 0.0945 \\
\hline \multirow{2}{*}{ Russia } & $G D P G \rightarrow$ & FDIF & 0.616 & 2 & 0.7347 \\
\hline & $F D I F \rightarrow$ & GDPG & 5.337 & 2 & 0.0694 \\
\hline \multirow{2}{*}{ India } & $G D P G \rightarrow$ & FDIF & 9.089 & 2 & 0.0106 \\
\hline & $F D I F \rightarrow$ & GDPG & 1.553 & 2 & 0.4601 \\
\hline \multirow{2}{*}{ China } & $G D P G \rightarrow$ & FDIF & 10.453 & 2 & 0.0054 \\
\hline & $F D I F \rightarrow$ & GDPG & 0.359 & 2 & 0.8356 \\
\hline \multirow{2}{*}{ South Africa } & $G D P G \rightarrow$ & FDIF & 6.484 & 2 & 0.0391 \\
\hline & $F D I F \rightarrow$ & GDPG & 0.156 & 2 & 0.9249 \\
\hline
\end{tabular}

\section{Discussion of Results}

\subsection{On Multicountry Basis}

The results for the BRICS countries reveal that FDIF is cointegrated with selected variables at $1 \%$ level of significance. The short-run estimates of the ARDL model (3) reveal that only trade openness (imports and exports) has a positive and significant impact on FDIF, indicating the importance of trade liberalization and the advantages of adopting outward-oriented trade policies in the short run, given differences among the BRICS economies in terms of imports and exports differentials. The positive impact result of trade openness on FDI inflow has been supported by many researchers, recently including Cleeve et al. (2015) and Oloyede and Kolapo (2018). The results of the long-run estimates of the ARDL model (4) showed that GDP growth has a positive and significant impact on FDIF, indicating that growth would afford FDI providers more profit substitutes and implying that FDI-positive externalities are subject to growth development in the host economy. For the BRICS economies, it seems that the significant scale market size (as for China and India), low labor cost (as for India and China), natural resources availability (as for Brazil and Russia), high-tech environment (as for China), and younger more energetic workforce (as for India) have acted as catalysts in attracting many foreign investors, hence bringing FDI to their host economies. The result of the long-run estimates falls in line with Yormirzoev (2015) for the CEE states alongside the Commonwealth of Independent States, Hlavacek and Bal-Domanska (2016) and Gherghina et al. (2019) for the CEE countries, and Asongu et al. (2018) and Maryam and Mittal (2020) for the BRICS countries.

Currency exchange rate and domestic investment are positive but have insignificant impact on FDI in both the short- and long-run models. The short-run result on currency exchange rate indicates no cost of capital advantages to either the host or the foreign (home) country in the short run, confirming the work of Nasir et al. (2017), who asserted that the effect of exchange rate and exchange rate volatility are more of a short-run phenomenon. The positive long-run result of currency exchange indicates a positive trend of changes between home currency exchange rate and FDI inflow, implying that an increase in host currency value would generate higher levels of profit for foreign investors and lower import costs, hence attracting more FDI inflow. For the domestic investment variable, the positive result showed the complementary relationship between domestic investment and FDI, meaning that economic advancements in terms of domestic investments would be reflected positively on inviting FDI inflow to the host country. The Toda Yamamoto causality test reveals a significant and unidirectional causality following from GDPG to FDIF, supporting the growth-led-FDI argument. 


\subsection{On Single-Country Basis}

The ARDL bound cointegration test concluded that FDIF is cointegrated with selected variables, indicating that all countries are significant at $1 \%$ level of significance, except Brazil, which is still significant but at $5 \%$ level. In the short run, all variables showed a significant lagged impact on FDIF with slight differences among countries. Results of the long-run estimates revealed varied results among the BRICS single countries. GDP growth has a positive and significant impact on FDIF for Russia, India, China, and South Africa, while it is positive and insignificant for Brazil. The growth positive impact supports our earlier conclusion whereby FDI-advantageous contribution is subject to the absorption capacity of the host economy. The growth result is consistent with Kumari and Sharma (2018) for India and Sunde (2017) for South Africa. For Brazil, the insignificant positive impact of growth on attracting FDI may be attributed to the conditional effect, whereby the highest growth productivity is attained when the recipient economy possesses a minimum threshold stock of human capital, attains a certain level of income, and is described as having sufficient absorptive capacity to perceive the advanced technology. In other words, FDI may or may not have an impact on economic growth but is conditional upon whether certain economic, financial, and environmental conditions are met in the host country.

The trade openness (import/export) variable has a negative and significant impact on FDIF for Russia, China, and South Africa, while for India, the impact is positive and significant on FDIF. For Brazil, the impact is positive and insignificant. In general, the result points to deviations in the export-import-oriented strategies among the BRICS economies in conjunction with discrepancies in terms of structure of trading portfolios, economic efficiencies, population size, environmental and financial market considerations, infrastructure development, and so on. For Russia, China, and South Africa, the result denoted that trade openness of economies does not serve as a precondition for FDI inflow, while for India, the opposite is true, where the country's outward-oriented trade policies would stimulate FDI inflow, reflecting the mutually reinforcing behavior between trade openness and FDI based on the open-door trade policy. For Brazil, it seems that the impact of trade openness on FDI depends on a threshold of the level of trade openness and the country's capability in terms of human capital, financial development, and capital formation.

The currency exchange (FXRate) results showed a positive and significant impact on FDIF for China and South Africa, while it had a negative and significant impact for Russia and India. For Brazil, the impact was positive and insignificant. The positive impact between the two variables for China and South Africa showed that appreciation in the home currency would increase profits for foreign investors based on lower prices for imports and higher returns, hence affecting FDI inflow positively. The negative and significant impact for Russia and India asserted that depreciation of a home currency can reduce the investment cost for foreign investors, hence increasing FDI inflow. The GFCF results pointed to a negative and significant impact on FDIF for Russia and South Africa, while for India and China the impact was positive and insignificant. For Brazil, the impact was negative and insignificant. The negative result for Russia and South Africa revealed that domestic investments may attract less attention from foreign investors when they consider investing in these countries. The positive result for India and China indicated the harmonious status between FDI and domestic investment, supporting the necessity to have other incentives, rather than domestic investments, to promote FDI inflow to their economies and backing our proposition of the positive relationship between capital formation and economic growth, hence FDI inflow.

The Toda Yamamoto causality test revealed a significant and unidirectional causality following from GDPG to FDIF for India, China, and South Africa, supporting the FDI hypotheses and implying that economic growth indicators in the host economy would attract higher levels of FDI inflow. The unidirectional causality results are consistent with those of Kumari and Sharma (2018) for India and Sunde (2017) for South Africa. For Brazil and Russia, there is a significant and unidirectional causality following from FDIF to GDPG, supporting the growth hypotheses and implying that an increase of FDI stock contributes to promotion of economic growth. Therefore, it seems there is a need to consider more prudent reforms in terms of eliminating barriers to have more access to inputs, technology, and financing, as well as improving domestic conditions to provide an efficient platform for attracting foreign investments, hence FDI inflow.

\section{Conclusions and Policy Implications}

For the BRICS economies, in this paper we tested for the short-run dynamics and the long-run cointegrating relationship between FDI inflow and economic growth over the period 1981-2018, while controlling for real exchange rate, trade openness, and domestic investment as proposed influential variables. The ARDL method was used to test for the long-run relationship of our FDI time series (panel) model. The ECM was used to test for the short-run dynamics, and the Toda Yamamoto (Toda \& Yamamoto, 1995) test was used for causality testing. 
On a multicountry basis, the test confirmed cointegration between FDIF and the selected variables in our model at $1 \%$ level of significance. Short-run estimates revealed that only Import \& Export has a positive and significant impact on FDIF, while GDP growth has a positive and significant impact on FDIF in the long run. On a single-country basis, the test revealed that FDIF is cointegrated with selected variables, revealing that all countries are significant at $1 \%$ level, except Brazil which is still significant but at $5 \%$ level. In the short run, all variables showed a significant lagged impact on FDIF with slight differences among countries. Results of the long-run estimates revealed varied results among the BRICS countries. In summary, economic growth, trade openness, currency exchange, and domestic investment would result in increased positive externalities across the BRICS economies in the long run through additional FDI inflow.

On the policy front, the following policy propositions can be derived in light of our results. First, BRICS governments could stimulate FDI through inducements to foreign investors, enhancing the macro-investment environment through relaxing trade barriers, tax incentives, infrastructure structure developments, and training to improve labor skills because FDI always comes with technology, allowing creation of a positive technological diffusion effect in the host country. Second, BRICS policymakers are advised to revisit their structural reforms in various sectors. In addition, they could prioritize the economic growth reforms by, for example (among other measures) formulating dynamic monetary controls that would stabilize the economy and reduce exchange rate variations, as well as instigating reforms on domestic investment, capital formation, and trade openness. This may be quite appropriate given the differences among the BRICS members in terms of their global trade-oriented policy structures and export trends. Third, while there is high growth potential for most BRICS economies, governments are encouraged to continue furthering trade liberalization through export-oriented development policy and reducing trade tariffs and nontariff barriers to enlarge trade, hence enhancing economic growth, which would serve as a requirement for attracting FDI and benefitting from its positive externalities. This is crucial given the complementary discrepancies in the comparative advantages among the BRICs members. Fourth, the presence of unidirectional causality following from GDPG to FDIF for India, China and South Africa and the presence of unidirectional causality following from FDIF to GDPG for Brazil and Russia would encourage support for cross-border collaboration among the BRICS economies, where countries with a strong competitive edge could help in knowledge and technology transfers, which could improve productivity and deepen the competitiveness of industries within the BRICS nations.

As suggestions for future studies, while our results indicate the importance of economic growth in stimulating FDI inflow in the short- and long-run estimates, the complete benefits may not be achieved in the absence of well-functioning financial markets and human capital development, in addition to well-functioning credit markets, labor regulatory quality, and the overall institutional environment. As such, these macrovariables are critical determinants for FDI inflow because development in these factors can adversely limit an economy's ability to benefit from the FDI inflow positive externalities.

\section{References}

Abdouli, M. \& Hammami, S. (2017). Investigating the causality links between environmental quality, foreign direct investment and economic growth in MENA countries. International Business Review, 26(2), 264-278. https://doi.org/10.1016/j.ibusrev.2016.07.004.

Adams, S. \& Opoku, E. E. O. (2015). Foreign direct investment, regulations and growth in sub-Saharan Africa. Economic Analysis and Policy, 47, 48-56. https://doi.org/10.1016/j.eap.2015.07.001.

Agrawal, G. (2015). Foreign direct investment and economic growth in BRICS economies: A panel data analysis. Journal of Economics, Business and Management, 3(4), 421-424. https://doi.org/10.7763/JOEBM.2015.V3.221.

Alfaro, L., Chanda, A., Kalemli-Ozcan, S. \& Sayek, S. (2004). FDI and economic growth: the role of local financial markets. Journal of International Economics, 64(1), 89-112. https://doi.org/10.1016/S0022-1996(03)00081-3.

Alfaro, L., Chanda, A., Kalemli-Ozcan, S. \& Sayek, S. (2010). Does foreign direct investment promote growth? Exploring the role of financial markets on linkages. Journal of Development Economics, 91(2), 242-256. https://doi.org/10.1016/j.jdeveco.2009.09.004.

Asongu, S., Akpan, U. S. \& Isihak, S. R. (2018). Determinants of foreign direct investment in fast-growing economies: evidence from the BRICS and MINT countries. Financial Innovation, 4(1), 26.

Asteriou, D. \& Hall, S. G. (2007). A Modern Approach Using Eviews and Microfit (Revised Edition). Palgrave McMillan, New York. https://doi.org/10.1186/s40854-018-0114-0. 
Balakrishnan, M. S., Muhammad, N., Sikdar, A., Rogmans, T. \& Ebbers, H. (2013). The determinants of foreign direct investment in the Middle East North Africa region. International Journal of Emerging Markets, 8(3), 240-257. https://doi.org/10.1108/17468801311330310.

Balasubramanyam, V. N., Salisu, M. \& Sapsford, D. (1996). Foreign direct investment and growth in EP and IS countries. The Economic Journal, 106(434), 92-105. https://doi.org/10.2307/2234933.

Bani-Mustafa, A., Matawie, K. M., Finch, C. F., Al-Nasser, A. \& Ciavolino, E. (2019). Recursive residuals for linear mixed models. Quality \& Quantity, 53(3), 1263-1274.

Borensztein, E., de Gregorio, J. \& Lee, J. W. (1998). How does foreign Direct Investment affect economic growth? journal of international economics, 45, 115-135. https://doi.org/10.1016/S0022-1996(97)00033-0.

Box, G. E. P. (1953). Non-normality and tests on variances. Biometrika, 40(3/4), 318-335. https://doi.org/10.1093/biomet/40.3-4.318

Brown, R. L., Durbin, J. \& Evans, J. M. (1975). Techniques for testing the constancy of regression relationships over time. Journal of the Royal Statistical Society: Series B (Methodological), 37(2), 149-163. https://doi.org/10.1111/j.2517-6161.1975.tb01532.x.

Campa, J. M. (1993). Entry by foreign firms in the United States under exchange rate uncertainty. The Review of Economics and Statistics, 614-622. https://doi.org/10.2307/2110014.

Chakraborty, D., Mukherjee, A., Sikdar, S., Paul, A., Ghosh, S. \& Khuda-Bukhsh, A. R. (2012). [6]-Gingerol isolated from ginger attenuates sodium arsenite induced oxidative stress and plays a corrective role in improving insulin signaling in mice. Toxicology Letters, 210(1), 34-43. https://doi.org/10.1016/j.toxlet.2012.01.002.

Chan, M. W. L., Hou, K., Li, X. \& Mountain, D. C. (2014). Foreign direct investment and its determinants: A regional panel causality analysis. The Quarterly Review of Economics and Finance, 54(4), 579-589. https://doi.org/10.1016/j.qref.2013.07.004.

Cleeve, E. A., Debrah, Y. \& Yiheyis, Z. (2015). Human capital and FDI inflow: An assessment of the African case. World Development, 74, 1-14. https://doi.org/10.1016/j.worlddev.2015.04.003.

de Mello Jr, L. R. (1997). Foreign direct investment in developing countries and growth: A selective survey. The Journal of Development Studies, 34(1), 1-34. https://doi.org/10.1080/00220389708422501.

Dickey, D. A. \& Fuller, W. A. (1979). Distribution of the estimators for autoregressive time series with a unit root. Journal of the American Statistical Association, 74(366a), 427-431. https://doi.org/10.2307/2286348.

Dinh, T. T.-H., Vo, D. H. \& Nguyen, T. C. (2019). Foreign Direct Investment and Economic Growth in the Short Run and Long Run: Empirical Evidence from Developing Countries. Journal of Risk and Financial Management, 12(4), 176. https://doi.org/10.3390/jrfm12040176.

Durham, J. B. (2004). Absorptive capacity and the effects of foreign direct investment and equity foreign portfolio investment on economic growth. European Economic Review, 48(2), 285-306. https://doi.org/10.1016/S0014-2921(02)00264-7.

Gherghina, Ş., Simionescu, L. N. \& Hudea, O. S. (2019). Exploring Foreign Direct Investment-Economic Growth Nexus-Empirical Evidence from Central and Eastern European Countries. Sustainability, 11(19), 1-33. https://EconPapers.repec.org/RePEc:gam:jsusta:v:11:y:2019:i:19:p:5421-:d:272341

Hansen, H. \& Rand, J. (2006). On the causal links between FDI and growth in developing countries. World Economy, 29(1), 21-41. https://doi.org/10.1111/j.1467-9701.2006.00756.x .

Hasli, A., Ho, C. S. \& Ibrahim, N. A. (2015). Determinants of FDI inflow in Asia. Journal of Emerging Economies and Islamic Research, 3(3), 1-9.

Hermes, N. \& Lensink, R. (2003). Foreign direct investment, financial development and economic growth. The Journal of Development Studies, 40(1), 142-163. https://doi.org/10.1080/00220380412331293707.

Hlavacek, P. \& Bal-Domanska, B. (2016). Impact of foreign direct investment on economic growth in Central and Eastern European countries. Inžinerine Ekonomika, 294-303. https://doi.org/10.5755/j01.ee.27.3.3914.

Iamsiraroj, S. \& Ulubaşoğlu, M. A. (2015). Foreign direct investment and economic growth: A real relationship or wishful thinking? Economic Modelling, 51, 200-213. https://doi.org/10.1016/j.econmod.2015.08.009.

Johansen, S. (1991). Estimation and hypothesis testing of cointegration vectors in Gaussian vector autoregressive models. Econometrica: Journal of the Econometric Society, 1551-1580. https://doi.org/10.2307/2938278. 
Ikechi, K. \& Anayochukwu, O. (2014). Capital Formation and Economic Growth in Nigeria. Global Journal of Human-Social Science, 14(4), 42-58.

Kathuria, V. (2019). Growth and Investment: Testing for the Relationship for South Asian Countries. Millennial Asia, 10(3), 337-371. https://doi.org/10.1177/0976399619879890.

Kumari, A. \& Sharma, A. K. (2018). Causal relationships among electricity consumption, foreign direct investment and economic growth in India. The Electricity Journal, 31(7), 33-38. https://doi.org/10.1016/j.tej.2018.08.004.

Lily, J., Kogid, M., Mulok, D., Thien Sang, L. \& Asid, R. (2014). Exchange rate movement and foreign direct investment in ASEAN economies. Economics Research International, 2014. https://doi.org/10.1155/2014/320949.

Liu, X., Shu, C. \& Sinclair, P. (2009). Trade, foreign direct investment and economic growth in Asian economies. Applied Economics, 41(13), 1603-1612. https://doi.org/10.1080/00036840701579176.

Makiela, K. \& Ouattara, B. (2018). Foreign direct investment and economic growth: Exploring the transmission channels. Economic Modelling, 72, 296-305. https://doi.org/10.1016/j.econmod.2018.02.007.

Malik, R. A. \& Savadatti, P. M. (2018). Trends and pattern of fdi inflow in BRICS: A time series analysis. Journal of Management (JOM), 5(4).

Maryam, J. \& Mittal, A. (2020). Foreign direct investment into BRICS: an empirical analysis. Transnational Corporations Review, 1-9. https://doi.org/10.1080/19186444.2019.1709400.

Mencinger, J. (2003). Does foreign direct investment always enhance economic growth? Kyklos, 56(4), 491-508. https://doi.org/10.1046/j.0023-5962.2003.00235.x.

Meyer, D. F. \& Sanusi, K. A. (2019). A Causality Analysis of the Relationships Between Gross Fixed Capital Formation, Economic Growth and Employment in South Africa. Studia Universitatis Babes-Bolyai Oeconomica, 64(1), 33-44. https://doi.org/10.2478/subboec-2019-0003.

Mittal, S. \& Mittal, M. (2019). Causal relationship between FDI and trade in BRICS nations: a panel data approach. International Journal for Research in Engineering Application \& Management (IJREAM), 04(10), 2454 9150. https://doi.org/10.18231/2454-9150.2018.1335.

Nasir, M. A., Ahmad, F. \& Ahmad, M. (2017). Foreign Direct Investment, Aggregate Demand Conditions and Exchange Rate Nexus: A Panel Data Analysis of BRICS Economies. Global Economy Journal, 17(1), 20160012. https://doi.org/10.1515/gej-2016-0012.

Oloyede, J. A. \& Kolapo, F. T. (2018). Sensitivity of Foreign Direct Investment to Macroeconomic Variables in Nigeria. Advances in Social Sciences Research Journal, 5(7).

Osinubi, T. S. \& Amaghionyeodiwe, L. A. (2009). Foreign direct investment and exchange rate volatility in Nigeria. International Journal of Applied Econometrics and Quantitative Studies, 6(2), 83-116.

Pegkas, P. (2015). The impact of FDI on economic growth in Eurozone countries. The Journal of Economic Asymmetries, 12(2), 124-132. https://doi.org/10.1016/j.jeca.2015.05.001.

Pesaran, M. H., Shin, Y. \& Smith, R. J. (2001). Bounds testing approaches to the analysis of level relationships. Journal of Applied Econometrics, 16(3), 289-326. https://doi.org/10.1002/jae.616.

Phillips, P. C. B. \& Perron, P. (1988). Testing for a unit root in time series regression. Biometrika (Vol. 75, Issue 2). https://doi.org/10.1093/biomet/75.2.335.

Prabhakar, A. C., Azam, M., Bakhtyar, B. \& Ibrahim, Y. (2015). Foreign direct investment, trade and economic growth: A new paradigm of the BRICS. Modern Applied Science, 9(12), 32-42. https://doi.org/10.5539/mas.v9n12p32.

Procázka, P., Maitah, M. \& Pachmann, A. (2015). Corruption and its Influence on Economy with Focus on Inflow of Foreign Direct Investment. Modern Applied Science, 9(12), 213. https://doi.org/10.5539/mas.v9n12p213.

Ramirez, L. \& Mordecki, G. (2014). Investment, growth and employment: VECM for Uruguay.

Ranco, G., Aleksovski, D., Caldarelli, G., Grčar, M. \& Mozetič, I. (2015). The effects of Twitter sentiment on stock price returns. PloS One, 10(9). https://doi.org/10.1371/journal.pone.0138441.

Ranjan, V. \& Agrawal, G. (2011). FDI inflow determinants in BRIC countries: A panel data analysis. International Business Research, 4(4), 255. https://doi.org/10.5539/ibr.v4n4p255. 
Sağlam, Y. (2017). FDI and Economic Growth in European Transition Economies: Panel Data Analysis. Journal of Yaşar University, 12(46), 123-135.

Samantha, N. \& Haiyun, L. (2017). The Impact of FDI on the Economic Growth of Sri Lanka: An ARDL Approach to Co-integration. International Journal of Innovation and Economic Development, 3(5), 70-82. https://doi.org/10.18775/ijied.1849-7551-7020.2015.35.2006.

Sazanami, Y., Yoshimura, S. \& Kiyota, K. (2003). Japanese foreign direct investment to East Asia and exchange rate policies: Some longer term policy implications after the crisis. Keio Economic Studies, 40(1), 1-26.

Shuaib, I. M. \& Ndidi, D. E. (2015). Capital formation: impact on the economic development of Nigeria 1960-2013. European Journal of Business, Economics and Accountancy, 3(3), 23-40.

Silajdzic, S. \& Mehic, E. (2016). Absorptive capabilities, FDI, and economic growth in transition economies. Emerging Markets Finance and Trade, 52(4), 904-922. https://doi.org/10.1080/1540496X.2015.1056000.

Sunde, T. (2017). Foreign direct investment, exports and economic growth: ADRL and causality analysis for South Africa. Research in International Business and Finance, 41, 434-444. https://doi.org/10.1016/j.ribaf.2017.04.035.

Toda, H. Y. \& Yamamoto, T. (1995). Statistical inference in vector autoregressions with possibly integrated processes. Journal of Econometrics, 66(1-2), 225-250. https://doi.org/10.1016/0304-4076(94)01616-8.

Udomkerdmongkol, M., Morrissey, O. \& Görg, H. (2009). Exchange rates and outward foreign direct investment: US FDI in emerging economies. Review of Development Economics, 13(4), 754-764. https://doi.org/10.1111/j.1467-9361.2009.00514.x.

Ugochukwu, U. S. \& Chinyere, U. P. (2013). The impact of capital formation on the growth of Nigerian economy. Research Journal of Finance and Accounting, 4(9), 36-42.

Uwubanmwen, A. E. \& Ogiemudia, O. A. (2016). Foreign direct investment and economic growth: evidence from Nigeria. International Journal of Business and Social Science, 7(3), 89-103.

Vita, G. de \& Abbott, A. (2007). Do exchange rates have any impact upon UK inward foreign direct investment? Applied Economics, 39(20), 2553-2564. https://doi.org/10.1080/00036840600749748.

Yormirzoev, M. (2015). Influence of foreign Direct Investment on the Economic growth: The case of transitional economies in Central and Eastern Europe and the Commonwealth of Independent States. Вестник Удмуртского Университета. Серия «Экономика и Право», 1.

Zahonogo, P. (2016). Trade and economic growth in developing countries: Evidence from sub-Saharan Africa. Journal of African Trade, 3(1-2), 41-56. https://doi.org/10.1016/j.joat.2017.02.001.

Zhang, K. H. (2001). Does foreign direct investment promote economic growth? Evidence from East Asia and Latin America. Contemporary Economic Policy, 19(2), 175-185. https://doi.org/10.1111/j.1465-7287.2001.tb00059.x. 


\section{Notes}

Note 1. The BRICS is an economic cooperative group of nations distinguished as being fast-growing economies in the regional and global economy. The five BRICS nations attract significant attention from foreign investors and hence acquire momentous FDI inflow; they had an average of $26 \%$ of global FDI inflow in 2018, contributing $50 \%$ of the world's economic growth (Malik \& Savadatti, 2018). Geographically, BRICS economies are part of the G20, collectively account for $26.46 \%$ of the world land area, share $42.42 \%$ of the global population, hold $13.24 \%$ of the World Bank voting power and $14.91 \%$ of IMF quota shares, and have a combined nominal GDP of $23.2 \%$ of the gross world product and $32 \%$ of the world's GDP PPP (Iamsiraroj \& Ulubaşoğlu, 2015).

Note 2. Iamsiraroj and Ulubaşoğlu (2015) revealed that out of 108 studies on the FDI-growth nexus, less than half have indicated a positive and statistically significant impact, and almost a third have suggested a negative impact of FDI on growth, while $40 \%$ evidence a statistically insignificant interplay between FDI and growth. In addition, out of 880 regression estimates on the effect of FDI on growth, $43 \%$ of these estimates are positive and statistically significant, $26 \%$ are positive and statistically insignificant, $17 \%$ are negative and statistically significant, and $14 \%$ are negative and statistically insignificant.

Note 3. Other conditions may include political stability; government intervention; institutional legislations; a tax system; a country balance of payment; restrictions on capital inflow; inflation; the monetary and fiscal policies; the investment environment; trade policy; infrastructure; domestic savings; and development of financial market, financial and fiscal incentives, and capital accumulation. We also have the scale factors that affect the FDI inflow such as the size of the domestic market and growth prospects, reflecting the absorptive capacity of the host or the designated economy.

Note 4. In fact, extracting data from a single source of information enable us to overcome the consistency and measurement problems among proxies of variables.

\section{Copyrights}

Copyright for this article is retained by the author(s), with first publication rights granted to the journal.

This is an open-access article distributed under the terms and conditions of the Creative Commons Attribution license (http://creativecommons.org/licenses/by/3.0/). 